\title{
PROTECTION ON FREEDOM OF THE PRESS FOR FOREIGN JOURNALISTS AND JOURNALISTIC VISA IN INDONESIA
}

\author{
Fianka Aiza \\ Faculty of Law, Syiah Kuala University, Indonesia \\ Jalan Lingkar Kampus No. 9, Darussalam, Banda Aceh \\ Tel./Fax: +62-651-7552295 e-mail : Fiankaaiza@gmail.com \\ Lena Farsia \\ Faculty of Law, Syiah Kuala University, Indonesia \\ Jl. Putroe Phang No. 1 Darussalam, Banda Aceh, 23111 \\ Tel./Fax: +62-651-7552295 e-mail: farsia.lena@unsyiah.ac.id
}

\begin{abstract}
This study analyses how Indonesia enforces the law to protect the freedom of the press for foreign journalists and imposes strict visa regulations on them. The method used to conduct this research is the normative legal method. This study shows that Indonesia upholds human rights such as freedom of expression, but there are no specific legal rules to uphold such rights over foreign journalists. Rules are only available on the enactment of a journalistic visa. Therefore, it is recommended for Indonesia's Lawmakers to compose a new Law to uphold the rights and obligations of foreign journalists while they are in Indonesia and develop a monitoring body for foreign journalists so that Indonesia can ensure the protection of freedom of the press and the national security.
\end{abstract}

Keywords: Foreign journalists; Freedom of Press; Journalistic Visa.

\section{A. INTRODUCTION}

Freedom of expression is universally recognized as an essential part of the foundation of human rights. It is the cornerstone of democracy, the key to protecting all human rights, and fundamental to human dignity in its own right. It is also acknowledged that the right to freedom of expression is not absolute and that every country has developed some form of limitations on freedom of expression. ${ }^{1}$ United Nations has constituted the International standard for the Human Rights System, derived from international laws that include declaration, convention, and principles. The international standard for protecting human rights

\footnotetext{
${ }^{1}$ Mendel, Toby. "Restricting Freedom of Expression: Standards and Principles Background Paper for Meetings Hosted by the UN Special Rapporteur on Freedom of Opinion and Expression." Centre for Law and Democracy. 2010.
} 
Protection On Freedom Of The Press For Foreign

Journalists And Journalistic Visa In Indonesia

Student Journal of International Law

Fianka Aiza, Lena Farsia

Vol. 1, No. 1, (Agustus, 2021), pp. 56-65.

refers to the first document, the Universal Declaration of Human Rights. Several decades later established the International Covenant on Civil and Political Rights.

Freedom of the press is a right granted by the constitutional or legal protection relating to the media and published materials such as printed materials and non-printed materials without any restrictions or limitations from the government. ${ }^{2}$ Press freedom is a form of individual and political rights such as expressing thoughts, opinions, the right to freedom of communication, the right to obtain information. In its development as a "political institution (the fourth estate)," freedom of the press relates to the right of participation, control, and criticism. ${ }^{3}$ The freedom of the press is recognized internationally, as it is essential to protect the persons, in this case, a journalist, giving out information to the mass.

News has become an inseparable part of human life. ${ }^{4}$ Sound, fearless and independent journalism is vital in any democratic community. The United Nations, human rights chief, declared on $11^{\text {th }}$ June 2014 , emphasizing that it is necessary to ensure the safety of media workers who are experiencing attacks, harassment, and intimidation in recent years. ${ }^{5}$ Navi Pillay, UN High commissioner on Human Rights, stated on the panel discussion that the safety of journalists is crucial to the civil, political, economic, social, and cultural rights of all of us, as well as to the right to development. ${ }^{6}$

Indonesia has stipulated regulations on rights itself. These include the Constitution of Indonesia year 1945. Also Law No. 39 Year 1999 on Human Rights. There is also a specific regulation on the rights and obligations of the press, which is Law No. 40 Year 1999 on Press. These are the foundation in constituting the rights of the press or journalist.

Entering another country's territory means that a person needs to do what the country requires him/her to do. Passports are mainly the object of justifying

\footnotetext{
${ }^{2}$ https://referensi.elsam.or.id/2015/08/uu-nomor-40-tahun-1999-tentang-pers-2/

${ }^{3}$ Jurnal Dewan Pers, "Indonesia menyongsong Jakarta World Forum for Media Development 2016", Edisi 12, 2016, page 22

${ }^{4}$ Junaedi, Fajar. Jurnalisme penyiaran dan reportase televisi. Kencana, 2014.

5 https://www.ohchr.org/EN/NewYork/Stories/Pages/Safetyofjournalists.aspx, accessed on $10^{\text {th }}$ March 2020

${ }^{6}$ Panel discussion on the safety of journalists, took place on 23 September 2016 in Geneva, during $33^{\text {rd }}$ session of the Human Rights Council (HRC).
} 
Protection On Freedom Of The Press For Foreign

Journalists And Journalistic Visa In Indonesia

Student Journal of International Law

Fianka Aiza, Lena Farsia

Vol. 1, No. 1, (Agustus, 2021), pp. 56-65.

oneself in entering a foreign country. However, various kinds of visas are needed for many purposes, such as visa on arrival, student visa, business visa, family visa, journalistic visa, and many more. In documenting news or such, foreign journalists need to go through some procedures to obtain a journalist visa ${ }^{7}$. In holding a journalistic visa, one may enter Indonesia for the reasons such as documenting news, filming a documentary or a film, and many other journalistic activities they have specified in the document beforehand. There should be no problem for foreign journalists to enter Indonesia with a journalistic visa doing journalistic activities. On the other hand, there are many situations where foreign journalists enter Indonesia with visas such as business visa, trip visa, and other while doing journalistic activities.

The legal idealism in this thesis is that there are international standards, which are laws that countries must comply with and uphold. These regulations are UDHR and ICCPR, which are respected by states and ratified into national laws to regulate the importance of protecting human rights. Indonesia has upheld the protection of Human Rights by ratifying UDHR and ICCPR into Indonesian Law No. 39 Year 1999 on Human Rights, which includes protecting the Freedom of Expression. The freedom of expression for the Press and Journalists is regulated in Law No. 40 Year 1999 on The Press. All the rights and obligations of the National Press have been laid out in the regulation. Indonesia has guaranteed the freedom of the press in Indonesia by the Indonesian Constitution 1945. Freedom of speech is one of the fundamental human rights, and the right to seek and process information is essential. International standards for protecting human rights exist the ideal scenario or legal idealist, or das sollen.

However, how the law should be or das sein, the reality is different from what is idealized by the regulations. Rules may exist but are not implemented as they should be. Rules for upholding the freedom of expression for a local journalist have been explicitly set out in Law No. 40 Year 1999 On Press. However, it does not explicitly include foreign journalists as the subject of the law itself. The only law that regulates foreign journalists' existence was only mentioning them as a

\footnotetext{
7 The procedures to obtain journalist visa can be accessed through https://kemlu.go.id/newdelhi/id/pages/visa_wartawan_jurnalis/113/about-service
} 
Protection On Freedom Of The Press For Foreign

Journalists And Journalistic Visa In Indonesia

Student Journal of International Law

Fianka Aiza, Lena Farsia

Vol. 1, No. 1, (Agustus, 2021), pp. 56-65.

foreign entity in Law No. 11 Year 2006 on Immigration, which only mentions a type of visa and no further regulation on the rights and obligations on foreign journalists. So the reality is that the regulation on upholding the freedom of expression for foreign journalists does not exist, which is a disadvantage for both Indonesia and Foreign journalists.

Furthermore, cases such as foreign journalists violating the visa rules in Indonesia are abundant. Foreign journalists must hold a journalistic visa in order to do journalistic activities in Indonesia. However, many cases are that foreign journalists entered Indonesia with a tourist visa. It is easier to obtain and can be processed a lot faster than that of a journalist visa. This situation is violating Indonesia's terms of imposing restrictions on foreign entities with the Immigration Law. Nevertheless, Indonesia has not imposed a strict rule for foreign journalists and has not optimized the process of a Journalistic visa. Indonesia also does not have a law on the rights and obligations on the freedom of expression for foreign journalists in Indonesia.

Based on the problem stated above, this study analyzes how the International law standard protects the freedom of the press for foreign journalists and how the Indonesian government protects foreign journalists in Indonesia in the aspect of freedom of expression.

\section{B. RESEARCH METHOD}

The method that is used in this research is normative. In other words, this method may also be addressed as a normative juridical method. It consisted of few elements such as research on legal principles, research on legal systems, research on the level of legal synchronization, legal history research, and comparative law research. The method describes the law that existed to regulate the protection of journalists' rights in Indonesia and on the international level. This method means that the regulations are used to see how the implementation is on the field, whether fulfilled. 


\section{FINDINGS AND ANALYSIS}

\section{International Standard on the Protection on Freedom of Press}

Freedom of Expression is one of the fundamental International Human Rights recognized universally. The right is stipulated in both the Universal Declaration of Human Rights (UDHCR) and the International Covenant on Civil and Political Rights (ICCPR), which are the two primary international laws on the protection of Human Rights. It is a right that is recognized by Article 19 of UDHCR. Article 19 stipulated that "Everyone has the right to freedom of opinion and expression; this right includes freedom to hold opinions without interference and to seek, receive and impart information and ideas through any media and regardless of frontiers." According to the Universal Declaration, these rights are inherent in the worth of a human and are essential to keep domestic and international peace and safety ${ }^{9}$

ICCPR has also recognized the right to freedom of expression in article 19, which stated, "Everyone shall have the right to hold opinions without interference. It also mentioned that everyone shall have the right to freedom of expression; this right shall include freedom to seek, receive and impart information and ideas of all kinds, regardless of frontiers, either orally, in writing or print, in the form of art, or through any other media of his choice." 10

Freedom of expression is an essential element in a democracy. In fact, in the first session of the United Nations in 1946, before the adoption of the UDHCR or treaties, the UN General Assembly, through Resolution No. 59 (I) has previously stated that "the right to information is a fundamental human right and ... the standard of all freedoms which the United Nations declares". ${ }^{11}$ Freedom of speech or freedom of expression is currently acknowledged among regional and international human rights law. The right is expressed in Article 19 of the ICCPR,

\footnotetext{
${ }^{8}$ Article 19 of Universal Declaration of Human Rights

${ }^{9}$ Nickel, James W. Making sense of human rights: Philosophical reflections on the universal declaration of human rights. Univ of California Press, 1987.

${ }^{10}$ Article 19 of International Covenant on Civil and Political Rights

11 Rahmanto, T. Y. (2016). Kebebasan Berekspresi dalam Perspektif Hak Asasi Manusia: Perlindungan, Permasalahan dan Implementasinya Di Provinsi Jawa Barat. Jurnal HAM, 7(1), 4553.
} 
Protection On Freedom Of The Press For Foreign

Journalists And Journalistic Visa In Indonesia

Student Journal of International Law

Fianka Aiza, Lena Farsia

Vol. 1, No. 1, (Agustus, 2021), pp. 56-65.

Article 10 of the European Convention on Human Rights, Article 13 of the American Convention on Human Rights, and Article 9 of the African Charter on Human and Peoples' Rights. ${ }^{12}$ These regulations confirm that Freedom of Speech is an important matter that should be protected on a regional and International scale.

The right to freedom of expression is regulated and protected by every state in the world. The state's obligation to guarantee freedom of expression is regulated in international human rights instruments that are subsequently ratified into national law. Every country that bonds itself to international conventions must reach the goals the conventions set itself. As a member of (ICCPR), Indonesia must fulfill the rights stated in the convention to its citizen.

The right to freedom of expression derives from several specific rights, including the right to seek information and ideas, receive, and deliver them. Gathering information is essential to the media, specifically, journalists. The national courts have constantly confirmed that newsgathering activity is protected under the right to freedom of expression. ${ }^{13}$

\section{Journalistic Visa regulation for Foreign journalists in Indonesia}

Journalists observe and explain activities, record and analyze events, statements, laws, and any other proposals that may impact society, compile such information, and collect facts to educate individuals and groups or society. This concept of journalist encompasses all members of the media and their support staff and community media employees and "citizen journalists." ${ }^{14}$.

Freedom of expression expresses pronounced protection of media workers and journalistic activities. Indonesian Ministry of Home Affairs stated that the freedom of the foreign press to cover activities or make visits around the

\footnotetext{
12 Andrew Puddephatt. Freedom of Expression, The essentials of Human Rights, Hodder Arnold, p. 128. 2005.

13 https://www.article19.org/resources/international-standards-regulation-media-workers/, Accessed on $10^{\text {th }}$ December 2020

${ }^{14}$ La Rue, Frank. Report of the Special Rapporteur on the promotion and protection of the right to freedom of opinion and expression. 2011.
} 
Protection On Freedom Of The Press For Foreign

Journalists And Journalistic Visa In Indonesia

Student Journal of International Law

Fianka Aiza, Lena Farsia

Vol. 1, No. 1, (Agustus, 2021), pp. 56-65.

Indonesian territory is free in principle. However, procedures must be followed as

practiced by the Foreign Ministry. ${ }^{15}$ He added that the government does not limit the work of foreign journalists in Indonesia; it just further regulates the procedure. Adequate procedures are needed so that press freedom in Indonesia is not misused later.

Foreign journalists are categorized as foreign citizens; therefore, they must fulfill some requirements such as holding a passport and holding a visa for certain specific jobs to enter Indonesia. For every foreigner who enters Indonesia, the provisions have been regulated in Law no. 6 of 2011 concerning Immigration. Article 2 of the law stated that "Every person has the right to enter and exit Indonesia. ${ }^{16}$ In article 8 , It is stated that:

(1) Anyone who enters or leaves the Territory Indonesia is required to have a travel document valid and still valid.

(2) Every foreigner who enters Indonesian territory must have a valid and still valid Visa unless otherwise stipulated by law and international agreements. ${ }^{17}$

Article 10 also stated that "Foreigners who have met the requirements can enter Indonesian Territory after getting an approval to enter." ${ }^{18}$ Article 38 explains the type of visa which is visitation visa: "Visit visa is given to foreigners who will travel to the Indonesian Territory in order visits to government, educational, social

\footnotetext{
${ }^{15}$ http://www.ajisurabaya.org/2015/08/31/tjahjo-pers-asing-boleh-meliput-di-indonesia/, Accessed on November $20^{\text {th }}, 2020$

${ }^{16}$ Article 2 of Law No. 6 Year 2011 regarding Immigration

${ }^{17}$ Ibid.

${ }^{18}$ Ibid.
} 
Protection On Freedom Of The Press For Foreign

Journalists And Journalistic Visa In Indonesia

Student Journal of International Law

Fianka Aiza, Lena Farsia

Vol. 1, No. 1, (Agustus, 2021), pp. 56-65.

assignments culture, tourism, business, family, journalism, or stop by to continue

the travel to another country."19

For foreign journalists to be able to do journalistic activities within Indonesia must fulfill requirements set by the ministry of foreign affairs. The journalistic visa and visa are available at the Indonesian Embassy or representatives at the country where the applicant stays or at the nearest country if none, and there are procedures to obtain this visa ${ }^{20}$. Journalism visas are issued to foreign journalists/journalists who will enter Indonesia for media and film coverage. This visa can be obtained at the Embassy of the Republic of Indonesia, where the applicant lives, or in a nearby country if there is no Indonesian representative.

When foreign journalists enter Indonesia with the inappropriate visa such as business visas or tourist visas, shall be sanctioned under the law. This matter has been stated in Article 122 of Indonesian Law No. 6 Year 2011 on Immigration as the following:

Sentenced to a maximum imprisonment of 5 (five) years and a maximum fine of Rp. 500,000,000.00 (five hundred million rupiah) for:

(1) Any person who intentionally provides false or falsified letters or data or incorrect information to obtain a Visa or Stay Permit for himself or another person;

(2) Any Foreigner who intentionally uses a Visa or Stay Permit as referred above to enter and/or be in the Indonesian territory.

19 Ibid.

${ }^{20}$ Full procedures to obtain journalistic visa may be accessed through any Indonesia consulate websites, ex : https://www.indonesia.cz/consularvisa-service/procedures-for-journalists-filmshootings/ 
Protection On Freedom Of The Press For Foreign

Journalists And Journalistic Visa In Indonesia

Student Journal of International Law

Fianka Aiza, Lena Farsia

Vol. 1, No. 1, (Agustus, 2021), pp. 56-65.

Indonesia has clearly stated that every foreigner who wishes to enter

Indonesia must carry the appropriate visa according to their intention to enter. A journalist must enter Indonesia with a journalistic visa; otherwise, the newsgathering activities they conduct in Indonesia are illegal. Foreign journalists must respect and uphold Indonesia's regulations while they are in the territory.

\section{CONCLUSION}

The research has found that freedom of expression and freedom of the press are two related rights that have been guaranteed by International law and Indonesian law. UDHR and ICCPR have set out the International standard on recognizing and protecting human rights. Therefore, all persons within the territory of Indonesia have their rights protected by the law. However, it is also found that by practice, foreign journalists may not obey the visa provisions set out by Indonesian law. Rather than using journalistic visas to do their activities, they use tourist visas instead because of the complicated bureaucracy. It is suggested for the Indonesian lawmaker to establish a new specific regulation to stipulate foreign journalists' rights and obligations. It is also suggested to establish a monitoring body for the foreign journalists, so the impact would be that Indonesia can monitor the activities of foreign journalists in Indonesia, and the foreign journalists may have good communication with regards to upholding Indonesian regulation.

\section{BIBLIOGRAPHY}

\section{A. Books and Journals}

Andrew Puddephatt, 2005, Freedom of Expression, The essentials of Human Rights, Hodder Arnold, p. 128.

Fajar Junaedi, 2014, Jurnalisme penyiaran dan reportase televisi. Kencana.

Jurnal Dewan Pers, 2016, "Indonesia menyongsong Jakarta World Forum for Media Development 2016", $12^{\text {th }}$ Edition.

La Rue, Frank. 2011. Report of the Special Rapporteur on the promotion and protection of the right to freedom of opinion and expression. 
Protection On Freedom Of The Press For Foreign

Journalists And Journalistic Visa In Indonesia

Student Journal of International Law

Fianka Aiza, Lena Farsia

Vol. 1, No. 1, (Agustus, 2021), pp. 56-65.

Mendel, Toby, 2010, "Restricting Freedom of Expression: Standards and Principles Background Paper for Meetings Hosted by the UN Special Rapporteur on Freedom of Opinion and Expression." Centre for Law and Democracy.

M Yakub Aiyub Kadir, 2009, The Human Rights in International Law and National Law (in Indonesian), Kanun Journal, Law Faculty, Syiah Kuala University, 48

Nickel, J. W, 1987, Making sense of human rights: Philosophical reflections on the universal declaration of human rights. University of California Press.

Rahmanto, T. Y, 2016, "Kebebasan Berekspresi dalam Perspektif Hak Asasi Manusia: Perlindungan, Permasalahan dan Implementasinya Di Provinsi Jawa Barat." Jurnal HAM, 7(1), 45-53.

Referensi HAM ELSAM "Undang Undang No. 40 Tahun 1999 Tentang Pers", $<$ https://referensi.elsam.or.id/2015/08/uu-nomor-40-tahun-1999-tentangpers- $2 />$

UN OHCHR, 2007, "State Responsibilities to regulate and adjudicate corporate activities under the United Nations core Human Right Treaties", Individual Report on the ICCPR, Report No. III.

B. Laws

Indonesian Law No. 39 Year 1999 on Human Rights

Indonesian Law No. 40 Year 1999 on Press

Indonesian Law No. 6 Year 2011 on Immigration

International Covenant on Civil and Political Rights

Universal Declaration of Human Rights 